2013

\title{
Humanity Bounded and Unbounded: The Regulation of External Self-Determination under International Law
}

Robert Howse

Ruti G. Teitel

New York Law School, ruti.teitel@nyls.edu

Follow this and additional works at: https://digitalcommons.nyls.edu/fac_articles_chapters

Part of the International Law Commons

Recommended Citation

7 LAW \& ETHICS OF HUMAN RIGHTS 155-184 (2013)

This Article is brought to you for free and open access by the Faculty Scholarship at DigitalCommons@NYLS. It has been accepted for inclusion in Articles \& Chapters by an authorized administrator of DigitalCommons@NYLS. 
Robert Howse* and Ruti Teitel

\title{
Humanity Bounded and Unbounded: The Regulation of External Self-determination under International Law
}

\begin{abstract}
One of the most complex and uncertain areas of international legal doctrine concerns how to deal with the aspiration of a people to achieve selfdetermination through the establishment of a new state and the related claim to a specific territory over which statehood is to be exercised. Recently, when the General Assembly of the United Nations referred to the International Court of Justice the question of the legality of the declaration of independence by Kosovar Albanians, the Court was given an opportunity to clarify and develop the law on external self-determination. Instead, the Court answered extremely narrowly, confining its analysis to the legality of the act of declaration without determining any consideration of international legal norms applicable to the act of secession that was being proposed. This article intends to fill the gap left by the ICJ's decision: first by critiquing the inadequacy and tensions visible in the existing doctrine and second by examining how recent developments in international law may allow for a more normatively coherent approach to the problem.
\end{abstract}

*Corresponding author: Robert Howse, NYU Law School, New York, NY, USA, E-mail: robert.howse@nyu.edu

Ruti Teitel, Department of Comparative Law, New York Law School, New York, NY, USA; London School of Economics, London, UK, E-mail: rteitel@nyls.edu

\footnotetext{
This article draws on the authors' prior work on the International Court of Justice (ICJ) advisory case concerning the secession of Kosovo, on Robert Howse's prior writing concerning Quebec secession in Canadian constitutional law and international law, especially Robert Howse \& Alissa Malkin, Canadians Are a Sovereign People: How the Supreme Court Should Approach the Reference on Quebec Secession, 76 CDN. BAR Rev. 186 (1997) and on various chapters in Ruti Teitel, Humanity's Law (2011). We are grateful for comments of participants at conferences at Humboldt University, Berlin and Cambridge University, as well as the Colloquium on Legal, Political and Social Philosophy at NYU Law School, and the College of Law \& Business, Ramat Gan, where we presented earlier versions of this article, and to Marko Milanovic and Ralph Wilde.
} 


\section{Introduction}

How should international law deal with the aspiration of a people to achieve self-determination through the establishment of a new state, and the related claim to a specific territory over which statehood is to be exercised? This is one of the most complex and uncertain areas of international legal doctrine, and there is not even agreement on the full range of norms that are implicated in the regulation of external self-determination. At the same time, issues raised for the philosophy of international law are also complex, engaging such matters such as the relationship of collective to individual rights, the problem of justifying ethno-nationalism, and the meaning of democratic equality. Recently, when the General Assembly of the United Nations referred to the International Court of Justice (ICJ), the question of the legality of the declaration of and independence by Kosovar Albanians, the Court was given an opportunity to clarify and develop the law on external self-determination. Instead the Court answered extremely narrowly, confining its analysis to the legality of the act of declaration itself ${ }^{1}$ (no rule of international prohibits merely talking about independence, not surprisingly); the Court eschewed any consideration of international legal norms applicable to the act of secession that was being proposed.

In a Separate Opinion one of the judges, Bruno Simma, chastised his colleagues in strong terms for not taking up the challenge of a broader consideration of the international legal issues raised by the project of Kosovar Albanian statehood. ${ }^{2}$ According to Simma, "the General Assembly's request deserves a more comprehensive answer, assessing both permissive and prohibitive rules of international law. This would have included a deeper analysis of whether the principle of self-determination or any other rule (perhaps expressly mentioning remedial secession) permit or even warrant independence (via secession) of certain peoples/territories." ${ }^{33}$ Simma implies, moreover, that international law may regulate external self-determination in ways other than through permitting, prohibiting, or conferring a right to, external self-determination itself. ${ }^{4}$

This article intends to take up Simma's plea for a "more comprehensive answer" to what international law says about external self-determination and to explore what would be required in order to provide such an answer, beginning from a critique of the inadequacy and tensions visible in the existing doctrine

1 Kosovo Advisory Opinion, 2010 I.C.J. (July 22) para. 78-121.

2 Judge Bruno Simma, Separate Opinion to Kosovo Advisory Opinion, 2010 I.C.J. (July 22) para. 3.

3 Id. para. 7.

4 Id. para. 6. 
and then examining how recent developments in international law may allow for a more normatively coherent approach to the problem.

Traditionally, for international lawyers, the problem of external self-determination was conceived of a struggle between an existing state - invoking the inviolability of existing territorial boundaries as a supreme principle of international law - and a movement-seeking statehood, invoking the supposed right to self-determination. The key moment in this struggle was seen as the decision of the international community-other states-as to whether or not to recognize the claim to statehood and thus to consecrate, as it were, the consequent disruption of existing territorial boundaries.

Two devices were used to manage the tension between the principle of inviolability of state boundaries and the right of self-determination. The first was to limit external self-determination claims to de-colonization and to remediating oppression where no other means was available. The other was to minimize disruption and instability from changes to existing territorial boundaries by using the principle of uti posseditis in the case of decolonization. This meant that the former colonial administrative boundaries became the new state's boundaries. By this means, one would in effect consecrate a successful external self-determination movement, even if it achieved its goals by force and did not have a legal claim to external self-determination, through "recognition" of the new state within the territory claimed by the successful movement. In our view, these devices not only entail the acceptance of considerable moral arbitrariness but also may well in fact lead to the exacerbation of violence, uncertainty, and instability.

We suggest that the reconceptualization of how international law is implicated in claims of external self-determination needs to be based on five interlocking notions.

First of all, greater clarity is required concerning the different moral bases of claims for external self-determination in order to understand the full implications of each for international legal regulation.

Second, while most traditional international law approaches have focused on the decision concerning the recognition of statehood as the decisive moment for normative regulation by international law, we believe that a "comprehensive answer" in Simma's sense means envisaging a continuum of international legal regulation, beginning from the way in which the campaign for statehood is waged and how it is responded to by the existing state and other groups and extending through to the actual use of state power to accomplish the aspirations for self-determination by the independence movement, once a new state has come into being. The "right" to self-determination on this approach does not get conceived as an entitlement at a given moment to be recognized by other states 
as an independent state, but rather is defined and limited through the regulation by appropriate norms of all the internationally legally relevant steps that are entailed in its realization.

Third, any right to external self-determination needs to be limited and relativized in light of other relevant rights and obligations in international law. Traditionally, to the extent that it might exist, the right to external self-determination was regarded as a trump card against a non-consenting existing state, asserting its territorial integrity. There is however much more at stake than a struggle between an existing state and a group within it that is seeking to form a new state. The notion we have in mind here is succinctly and well expressed by Jeremy Waldron: "self-determination is not the only principle in the constellation of political values recognized in international law; it must take its place alongside other principles such as human rights, democracy, and the rule of law." ${ }^{5}$ A claim to external self-determination by one group within an existing state may seriously disrupt the entitlements and affect the interests of other groups on that territory, and these may well be protected by international human rights law, which encompasses civil and political but also social, economic, and cultural rights.

Fourth and closely connected to the second and third notions, international law should operate in a normatively coherent manner in assigning legal burdens and responsibilities to all the relevant actors involved in a situation where a claim of external self-determination is asserted. This entails making both state and non-state actors responsible for the way that violence and other coercive actions (e.g. "ethnic cleansing") are used to either further or frustrate a claim of self-determination. International law today is evolving so as to regulate internal and external conflict, whether conducted by state or non-state actors, through a framework combining elements of human rights, the law of war, and international criminal justice, what Teitel calls Humanity Law. ${ }^{6}$ This framework abhors gaps in legal rights and responsibilities, especially concerning the protection of persons and peoples. ${ }^{7}$ That a claim for external self-determination has resulted in the recognition of the international community of statehood should not for example excuse the independence movement and its members of responsibility for acts committed prior to the achievement of statehood and the very same should go for the existing state or other groups who may have fought against the independence bid.

5 Jeremy Waldron, Two Conceptions of Self-determination, in The Philosophy of International Law 397 (Samantha Besson \& John Tasioulas eds., 2010).

6 Ruth Teitel, Humanity's Law 105-06 (2011).

$7 \mathrm{Id}$. at 106. 
Finally, while decisions about statehood and recognition and related matters (such as United Nations membership) have as their locus political or diplomatic institutions such as the UN Security Council, where only states are directly represented and the positions asserted are based as much or more on interests than on moral or legal principle, these and other statist institutions (even the International Court of Justice) do not have full legitimacy for regulating the exercise of external self-determination; they are not open to the direct participation of affected non-state actors in their deliberations, and especially they do not provide a forum for the assertion of claims of rights-violation by the victims nor the accountability of non-state actors. Political and diplomatic institutions should not endorse the right to external self-determination in such a way as to foreclose or prejudice the assertion of relevant claims and counterclaims in other more appropriate fora, regional human rights courts, for example.

The article is organized as follows. We begin by briefly articulating the main moral arguments that appear to underpin the claim to a right to external selfdetermination in international law, suggesting some of the challenges and difficulties in the translation of these moral arguments into a workable international legal principle for the regulation of claims to external self-determination. We then give a critical analysis of the way in which the question of external selfdetermination was addressed by the international legal system that emerged after the end of the Second World War. After this we focus on more recent attempts to address the question, in the context of the break-up of Yugoslavia and of Quebec/Canada. In these more recent attempts, we can see the reflection, to varying degrees, of the five notions posited above as central to what Simma calls "a comprehensive answer."

\section{The Moral Arguments that Underlie Claims for External Self-determination in International Law}

There are five kinds of moral argument that often underlie claims for external self-determination in international law. The first and least controversial is the argument against colonialism, the situation where the entire population or the majority within a given territory is ruled without their consent by a foreign power. $^{8}$ That self-rule is a justified response to such an injustice is not widely

8 Declaration on the Granting of Independence to Colonial Countries and Peoples, G.A. Res. 1514 (XV), U.N. GAOR, 15th Sess., Supp. No. 16 U.N. Doc. A/4684 (1960). 
disputed. Still even where the moral argument is undoubtedly very strong, it does not automatically decide the nature of the entitlement to territory, for the boundaries of the colony may themselves represent an injustice to other groups, may have been drawn through mass displacement of persons, and so on. The second argument is that of consent, the notion that the majority of the population in any defined area should be able to choose, through a convincing act of collective will (usually a referendum) to exit the larger polity and govern itself as a state within that defined area. ${ }^{9}$ This argument is based on the notion that it is inherently oppressive or unjust that any group of people should not be able to choose to live in a separate political community apart from others with whom they have previously shared a political community. It is an argument that has been strongly urged by Quebec separatists in asserting the claim of external self-determination..$^{10}$ It has been equally urged against the Quebec separatists by other groups, for example the Cree, who would not want to live in a state with a majority Francophone Quebecois population. ${ }^{11}$ This demonstrates the problem of almost infinite regress in this argument. It also illustrates the problem of the group self-defining the territory or which they seek to exercise self-rule. For the moral argument, even if compelling in the abstract, cannot itself establish an entitlement to any particular territory where the group might govern themselves.

There are also two kinds of moral argument for remedial external selfdetermination, which are often blurred in international legal discourse. The first is that where a group is denied internal self-determination, understood as the right to full democratic participation based upon equality of citizenship, ${ }^{12}$ or otherwise where the group is subject to persecution or oppression based on race or ethnicity, and alternatives for addressing these rights violations have not proven feasible, then it may be entitled to external self-determination as a remedy. The idea here is to ensure that the rights of members of the group are

9 See, e.g., the principle of consent is a term used in the context of the Northern Ireland Peace Process and one of the key points of the Good Friday Agreement.

10 Reference re Secession of Quebec, [1998] 2 S.C.R. 217.

11 Aboriginal Peoples and 1995 Quebec Referendum: A Survey of The Issues, sect. A1, available at http://www.parl.gc.ca/Content/LOP/researchpublications/bp412-e.htm\#1.

12 The logic here could extend intentional discrimination and persecution of a particular group to situations where, because the various groups in question have such great differences, or distrust between them goes extremely deep, it is simply impossible for them to effectively participate together in effective common institutions of democratic self-government. In other words, there is a de facto frustration of the exercise of the right to self-determination. We are grateful to Tom Nagel in particular for urging us to reflect on this kind of circumstance and whether it could lead to a morally justified claim to external self-determination. 
protected into the future and it seems only a state where they are the majority population can achieve this. But the moral argument does not really ground a claim to any particular territory, although it at least implies that the territorial settlement should be such as to minimize the chances of future persecution.

The other meaning of remedial external self-determination is backward rather than forward looking: The right to statehood is granted in response to some past injustice done to the group or its members (dispossession of land, etc.). This argument based on historical injustice also risks a kind of infinite regress, essentially opening up the injustices that may have been done to or between various groups through territorial settlements based on war, population displacement, natural catastrophes, and so forth over centuries. It raises issues of intergenerational justice and the rights of third parties who may have acquired an (arguably) innocent interest in the territory in question or certain defined rights on it. More generally, that a historical injustice has been done to a group and/or its members in itself does not make statehood morally compelling as the default remedy.

Finally, there is a moral argument that has an ethno-nationalist flavor to it, although often articulated particularly by philosophers sympathetic to it, such as Will Kymlicka ${ }^{13}$ and David Miller, ${ }^{14}$ in more general terms. There is a certain kind of group identity - Kymlicka calls it "culture"15 but it could be based on religion or language or a shared ethnicity, that is a special good or value, which cannot be adequately protected without the group or its leaders having the ability to exercise collective power over a defined territory. Some versions of this argument cash out in terms of a case for forms of political autonomy that fall short of statehood, aboriginal self-government for instance in the Canadian case. ${ }^{16}$ Whether and why this kind of group identity or affiliation is a good or value is a significant philosophical issue. At the same time, when this kind of moral argument is made it is often couched in terms of a claim over the group's traditional homeland, and thus the notion that the preservation and promotion of its identity is connected to control of a specific territory. Without fully rehearsing the philosophical debates here between different kinds of liberals, communitarians, and nationalists, the translation of this kind of argument into international legal principle raises a number of difficulties. The first is that more than one group may have a plausible claim that a certain given territory is an

13 See, e.g., Multicultural Citizenship: A New Theory of Minority Rights (1995).

14 David Mitler, On Nationalitry (1995).

15 Multicultural Citzenship, Supra note 13.

16 See Reference re Secession of Quebec, supra note 10; see Alan Cairns, Citizens Plus: Aboriginal Peoples and the Canadian State 40-42 (2000). 
essential part of their homeland - in such an instance one would need recourse to a range of additional principles in order to decide how to reconcile or adjudicate between the competing claims of external self-determination of the two or more groups. A second difficulty, less noticed but perhaps even more important, is that the exercise of collective power to preserve or promote the identity of a particular group or people may be in inherent tension with other values protected by international law, including individual freedom not to conform to group customs and traditions, equality of citizenship (which it should be recalled is fundamental to international law's conception of internal self-determination), and the rights of minorities. This is why great caution must be exercised in recognizing in international law any force to the argument for external self-determination based on the idea that the exercise of state power is necessary and desirable to favor the preservation of a particular group or people's distinctive identity. As we shall discuss later in this article, there is already case law under international law that illustrates the tension in question.

A third difficulty is that the argument often assumes that collective identity understood as something like culture or ethnicity or language is unitary, whereas there may be multiple allegiances, affiliations, or collective aspects of identity that are quite properly protected under international law, for example, gender, disability, and arguably to an increasing extent sexual orientation. It is really not possible or desirable to organize a state around the expression of these other kinds of collective allegiance or identity, but this does not mean that they should take lower priority as a matter of international legal principle nor that they can ignored in translating the ethno-national moral argument into international legal principle. For example, in the case of aboriginal self-government in Canada, aboriginal women did not identify with the project of selfgovernment in the same way as aboriginal men; indeed, they saw aspects of that project as threatening to their collective gender identity. ${ }^{17}$ In international law, self-determination is a right of "peoples"18 but what a people is remains undefined: there is a real danger of allowing ethno-nationalist conceptions of collective identity filling this gap and crowding out or subordinating other aspects of collective identity or affiliation that may be relevant to aspects of self-determination or collective rights even if they are not a basis for claims to statehood.

17 Elizabeth A. Asante, Negotiating Identity: Aboriginal Woman and the Politics of SelfGovernment, 25 Can. J. Native Stud. 1 (2005).

18 International Covenant of Civil and Political Rights, Dec. 16, 1966, 999 U.N.T.S. 171. 


\section{The Post-War International Legal System: The Struggle between Self-determination and Territorial Integrity}

Writing in the early 1960s, the Jewish-German émigré philosopher Leo Strauss made the provocative suggestion that the post-war, UN-Charter-based system of international law was premised on a "pious fraud." By requiring respect for existing state boundaries but also endorsing the self-determination of peoples, Strauss intimated, the system had to commit itself to "the assumption that all present boundaries are just, i.e. in accordance with the self-determination of peoples but this assumption is a pious fraud of which the fraudulence is more evident than the piety."19

Strauss here reveals only part of the "fraud." The post-war, UN-Charterbased system did not fundamentally alter the doctrine of recognition of new states (or more precisely resolve the ambiguities in that doctrine). Thus, on the one hand, one was called to respect existing territorial boundaries but on the other if a self-determination movement was effectively able to change the "facts on the ground" concerning the control of territory, it had a significant chance of gaining recognition of the "breakaway state." Thus while normatively consecrating existing state boundaries, international law also permitted existing states to recognize new states, based on de facto considerations such as the presence of government and territorial control. Thus, international law, although claiming stability of existing borders as a fundamental ordering principle, rewarded the unilateral disruption of those very boundaries by separatist movements, where successful on the ground. Once recognized as a state, the independence movement in control of a given territory would itself be entitled to the protection of the prohibition on the use force against its "territory," as well as the right of selfdefense, i.e. the right to use force against any attempt to resist its secession by the state from which it was breaking away. But, at the same time, and in obvious tension with the acceptance of recognition as Machtpolitik, the evolution of international human rights has given rise to the expectation that the right to self-determination would express and conform to the conception of human freedom, equality, and security at the normative core of human rights.

The history of post-war international legal practice bears witness to numerous attempts to rescue the global juridical order from the "pious fraud" (partly) identified by Strauss, reconciling self-determination as a normative ideal with

19 Leo Strauss, The City and Man (1963), see especially Introduction. 
territorial sovereignty, the prerogative of state recognition, and more recently, human rights.

\section{Decolonization}

The UN instruments on decolonization represent the first major effort to reconcile the ideal of self-determination and the principle of stable territorial integrity. The 1960 Declaration on the Granting of Independence to Colonial Countries and Peoples, ${ }^{20}$ without defining the meaning of a "people," states that "all peoples have the right to self-determination; by virtue of that right, they freely determine their political status and pursue their economic, social and cultural development."21 The Declaration further states: "All armed action or repressive measures of all kinds directed against dependent peoples shall cease in order to enable them to exercise peacefully and freely their right to complete independence, and the integrity of their national territory shall be respected." 22 But at the same time: "Any attempt aimed at the partial or total disruption of the national unity and the territorial of a country is incompatible with the purposes and principles of the United Nations..." 23

The solution to the reconciliation of the principles enunciated in paragraphs 1 and 4 with that enunciated in paragraph 6 is, of course, notorious: uti posseditis. The assertion of the right to self-determination and "complete independence" in paragraphs 1 and 4 was conditioned on the newly independent states having the same boundaries as the administrative boundaries that existed under colonialism. In this way, independence could be reconciled with stable territorial sovereignty. But of course these boundaries did not correspond, not even roughly, to the territorial patterns of organized political, social, economic, and cultural life prior to colonization: thus how could the imposition of uti possedetis, the denial of the freedom to choose a different pattern, really be compatible with the free determination of political status and economic, social, and cultural development?

Uti possedetis is most often justified as necessary to prevent the outbreak of violent conflict over territory in the process of decolonization. But as we have seen, most dramatically in parts of Africa, the result has often been the opposite.

20 Declaration on the Granting of Independence to Colonial Countries and Peoples, supra note 8 , at para. 1 .

21 Id. para. 4.

22 Id. para. 6.

23 Id. 
More cynically, uti possedetis had the advantage to the former colonial powers of extending colonial domination beyond formal decolonization through preserving a territorial configuration whose only basis for internal unity was often the economic, political, and administrative relationship to the colonial power. Boundaries in important ways determine the challenges of governance: the kind of infrastructure necessary for a national political economy (transportation, utilities, education, etc.) and the kind of differences (linguistic, cultural, religious) have to be managed in order to have a sustainable and just polity. Giving peoples independence from colonial rule while saddling them with whatever boundaries were created through the original (putatively unjust) colonial practices, regardless of the impact on the challenges of governance, was arguably a perpetuation rather than a solution to the "pious fraud" referred to by Leo Strauss.

The defenders or apologists of uti possedetis would point out that no one seemed to have a viable plan for restoring the territorial patterns of political, economic, social, and cultural life prior to colonization; nor would that have been, either, necessarily just given that the effects of colonization might well have rendered such patterns no longer viable in many cases. And even if disrupting those patterns through violent colonial conquest could be understood as unjust, this would not make the original patterns just; these patterns might in themselves be intertwined with injustices, or what we would now judge to be injustices, other than and prior to those of colonialism; therefore their simple restoration (even if viable under contemporary conditions) would not, even in the abstract, be a simply just remedy.

\section{Self-determination as Democratic Equality: The Declaration on Friendly Relations}

One could produce a certain normative clarity or at least honesty, transcending "pious fraud," through explicitly accepting (1) that any particular division of the world into territorial units defined as states will have strong elements of arbitrariness, will likely be shaped by past injustices, and there is no obvious normative principle that would inform judgment on and revision of borders, allowing a decision between the competing claims and historical narratives of different groups; (2) that the division of the world into territorial states and the protection of territorial integrity of those states is a necessary if not foundational building block of an international legal order; (3) that to the extent possible within the confines of such an international order one should encourage and 
support the mitigation or remedy of any injustices that might result from or be exacerbated by such an arbitrary division of the world (whether inequality of resources, or vulnerability or persecution of minorities, to give but two examples).

How then to make sense of the idea of a legal entitlement of peoples to selfdetermination of peoples? The answer apparently given in the 1970 UN Declaration on Principles of International Law Concerning Friendly Relations and Cooperation among States in accordance with the Charter of the United Nations ${ }^{24}$ is that self-determination really means democratic equality. A "people" is just the collection of individuals that one finds within the territory of any given existing state: the entitlement to self-determination of this "people." Thus according to the 1970 Declaration, the right to self-determination is apparently fulfilled where a state "is possessed of a government representing the whole people belonging to the territory without distinction as to race, creed or color. $" 25$ It is true that the opening paragraph of the Declaration seems to suggest a rather different normative thrust to the right to self-determination in stating that "the establishment of a sovereign and independent State, the free association or integration with an independent State or the emergence into any other political status freely determined by a people constitute modes of implementing the right of self-determination..."26 (emphasis added). But this is "not to be construed as authorizing or encouraging any action which would dismember or impair totally or in part the territorial integrity or political unity"27 of an existing state.

What the Declaration does leave open is the possible legality or legitimacy of modes of realizing self-determination that do entail disrupting existing territorial state boundaries in the case where that existing state denies democratic equality, i.e. a "government representing the whole people belonging to the territory without distinction as to race, creed, and color." 28 "External" self-determination thus becomes a legal remedy: the consequences, as suggested in the Declaration are that the state denying democratic equality cannot forcibly resist the selfdetermination attempt even if it entails dismemberment of that state, and also that, legally, other states can come to the aid of the self-determination movement.

24 Declaration on Principles of International Law concerning Friendly Relations and Co-operation among States in accordance with the Charter of the United Nations, U.N. Doc A/RES/25/ 2625 (1970), preamble [hereinafter Declaration on Principles of International Law].

25 Id. art. 1.

26 Id. Emphasis added.

27 Id.

28 Id. 
The acceptance of external self-determination as a remedy for the denial of democratic equality would seem to indicate a major qualification on the principle of territorial integrity of existing states, and indeed one based on an ideal of internal political justice. It is hard to imagine such a counter-Westphalian development except in light of the emergence of human rights as a shaping and indeed transformative force in international law. Yet in international legal practice it was already foreshadowed by the hint in the Report of the League of Nations Commission on the Aland Islands question" 29 that "oppression" might be one of the rare or only justification(s) for secession and in political theory by, for example, purely political Zionism, which had as its basis the notion that independent statehood is a solution - in a world of sovereign states perhaps the only solution - to the problem of persistent discrimination or persecution, to the denial of democratic equality, either formally or as a matter of social fact, or both.

But original political Zionism was philosophically consistent in recognizing discrimination or persecution might generate a valid claim to statehood by a persecuted group but not necessarily a claim that trumped that of any counterclaims of other inhabitants, to any given territory. Thus, original political Zionism generated any number of proposals for possible territories on which a Jewish homeland might be established, including for example what is today Uganda. Herzl, the founder of political Zionism, wrote: "We are one people - our enemies have made us one without our consent."30

By accepting the principle that the denial of democratic equality by a government of all the people in a given territory gives a persecuted or discriminated group within that territory a legal remedy of external self-determination, the 1970 UN Declaration indirectly or subtly introduces an additional or second meaning to "people" - a "nation" in Herzl's sense, as defined by the persecution or discrimination in question.

Fatefully, the Declaration, while opening up the possibility of external selfdetermination, provides no principle for determining over what territory such a right might be exercised. Does the remedy simply trump any rights or claims of other inhabitants of such a territory? This occurs when the remedy for the denial of democratic remedy is no longer a remedy exercised by the entire people on the territory of the state in question, i.e. the replacement of the government of that people as a whole with a government that respects democratic equality, an ancestral homeland, for example, or part of the territory of the existing state

29 The Aaland Islands Question (On Jurisdiction), Report of the International Committee of Jurists, League of Nations Official Journal, P.C.I.J. Special Supplement No. 3 (1920) (ser. x) No. x. 30 Theodor Herzl, The Jewish State (1896). 
where they constitute a majority. As noted above, in our discussion of the moral arguments, one aspect of the difficulty is that the remedy of external selfdetermination is only available to groups who are organized in such a way as to be able to stake a claim to some territory or other. Where the people who are denied democratic equality do not have some sort of claim to an identifiable, bounded territory, they must content themselves with other remedies, either changing the practices of the government of the existing state or exit (immigration to another state where they are not denied democratic equality).

The 1970 Declaration, encouraged territorial claims based on extrinsic normative principles, including ethnic or even racist ideologies or historical narratives, which connect people to territory based on "blood and belonging." 31 of course, as we know there are often counter-ideologies or counter-narratives of other groups, in contestations over the same or overlapping territory. Yet, there are no adequate principles intrinsic to the right of self-determination itself by which such competing claims to territory could be decided or mediated.

The possibility of international law being co-opted by ethno-nationalism ${ }^{32}$ is further increased by indeterminacy in the content of the idea of democratic equality or more precisely "a government representing the whole people belonging to a territory without distinction as to race, creed or color." ${ }^{33}$ For the moral argument concerning a remedy for discrimination or persecution can be combined or conflated with the different moral argument about the need to exercise collective power to protect a particular group identity or "culture." As noted earlier, philosophers such as Will Kymlicka have suggested that group identity or cultural context are themselves vital goods, on which meaningful individual freedom or autonomy depends, and that this may be the basis for some entitlement to the exercise by a group of self-government or a measure of political autonomy over a given territory. In this regard, Kymlicka quotes approvingly a proposal for a European minority rights convention that would provide that "persons belong to a national minority shall have the right to have at their

31 Declaration on Principles of International Law, preamble, supra note 24.

32 We use ethno-nationalism in a broad sense here to denote in Miller's sense the idea of a "people" as having a "distinct, common character of its own," a shared identity makes it a "nation," and the notion that "every nation must have a homeland," taken together. The "distinct common character" could be based on religious, ethnic, linguistic, racial, or historical notions as long as they play an exclusionist, particularist identity-forming function. See DavID Miller, On Nationality 25 (1995).

33 Declaration on Principles of International Law, preamble, supra note 24. 
disposal appropriate local or autonomous authorities or to have a special status, matching this specific historical and territorial situation...."34 At first glance, this would seem to go beyond the entitlement to a government that represents the entire people without distinction as to race, creed, or color. But does a government "represent the entire people" if it provides for instance public funding for education only in the majority language or provides publicly funded schools where the majority religion is taught but not minority religions? What about where, because of majoritarianism or through application of the formal equality principle of "one person, one vote," only members of the majority ethnic group are elected to public office, i.e. because of the individual or private preferences of those belonging to the majority group to be governed by "their own" not do to governmental discrimination as such? If majoritarianism itself tends to preclude representing the entire people in the normatively meaningful sense, then democratic equality itself could be interpreted as implying a right of minorities to some kind of political autonomy or "special status" within a certain territory, the denial of which could then, in turn, be considered to provide a basis for external self-determination. The problem here is not solved but rather arguably only exacerbated by the broad terms in which minority rights are defined in Article 27 of the UN Covenant on Civil and Political Rights. ${ }^{35}$

\section{Badinter and the Balkans}

The break-up of Yugoslavia gave rise to new efforts to recast the structure of international legal normativity as it applies to self-determination and secession. One sees here the emergence, albeit very imperfectly and unevenly, of some of the central notions that, we have suggested, should govern a comprehensive approach to external self-determination under international law. On the other hand, some of the efforts in question, especially the Badinter Commission, tended to obscure or avoid a direct consideration of the moral arguments for external self-determination and their suitability for informing international legal principle.

First, there was an acknowledgement, at least in Europe, that the right to external self-determination is not a "trump" that overrides or displaces other relevant international legal norms: the third notion that we argue should govern

34 Will Kymlicka, Minority Rights in Political Philosophy and International Law, in THE Philosophy of International LaW 377, 383 (Samantha Besson \& John Tasioulas eds., 2010). 35 UN Covenant on Civil and Political Rights, art. 27, Mar. 23, 1976, 14668 U.N.T.S. 172. 
any "comprehensive answer." Instead the right to external self-determination is properly conditioned on these norms (the second of our five notions). By setting up a framework for recognition of statehood that contained a significant number of human rights conditionalities, the European Union appeared to be boldly challenging the gap between the aspiration of international law to regulate normatively self-determination and secession and the reality of the consecration of rapports de force through the doctrine of recognition. The European Union's guidelines were based on the premise - radical and progressive - that this gap must be closed. This is an expression, at least partial, of the second notion in our approach that of a continuum of international legal regulation.

In the Guidelines, the EU affirmed its "attachment to ... the principle of selfdetermination." ${ }^{36}$ This principle governed the recognition of new states provided these states respected "the rule of law, democracy and human rights" and provided "guarantees for the rights of ethnic and national groups and minorities." 37 But, in addition, the EU also required as a condition for recognition "respect for the inviolability of all frontiers which can only be changed by peaceful means and by common agreement." 38 Further, "The Community and its member States will not recognize entities which are the result of aggression."39

The secessionist movement might even have been driven by ethnic nationalism, it might have engaged in violent struggle against other groups, but it would still have the possibility of recognition provided that the resulting state committed itself to democracy, human rights, and some version of multiculturalism (a further declaration on Yugoslavia ${ }^{40}$ envisaged as an condition for recognition adhesion to a new legal instrument on minority rights, which never in the event came into existence). One of course must be careful to underline that the EC Guidelines did not suggest that under the international law of self-determination, there was a requirement that existing states confer recognition: recognition remained within the discretion of existing states. But such discretion could be exercised legitimately and in conformity with international law principles, where the independence movement representing the future state made the required human rights commitments.

36 European Communities Declaration on the "Guidelines on the Recognition of New States in Eastern Europe and the Soviet Union," Dec. 16, 1991.

37 Id.

38 Id.

39 Id.

40 Declaration on Yugoslavia, Extraordinary EPC Ministerial Meeting, Brussels, Dec. 16, 1991. 
How could this be reconciled with "respect for inviolability of all frontiers"? In order to avoid having to directly confront the moral arguments for external self-determination at issue and the question of how they translate into legal principle, the Commission interpreted the course of events in Yugoslavia in such a way that it could present the trigger for recognition as something other than unilateral secession. Thus, the Commission interpreted the various events engendered by the secessionist movements, such as plebiscites in favor of independence in the republics, the breakdown in the functioning of the institutions of federal of governance in Yugoslavia, and the state of war itself, as the "process of dissolution" of Yugoslavia as a federal state.

In applying the criteria for recognition in the Guidelines and the Declaration, the Badinter Commission could make it appear as though it was simply responding to the challenge of an orderly state succession, in the circumstances of the failure or collapse of Yugoslavia. It could avoid the implication of legitimizing secession and consecrating its territorial consequences. While claiming to make a purely factual determination of the failure or dissolution of the Yugoslav federal state, the Badinter Commission shuttled between facts and norms in order to hide its true game. ${ }^{41}$ Thus, while purporting to make a purely factual determination about the "process of dissolution," the Commission introduced indirectly normative considerations that would affect a judgment on the legitimacy of secession: i.e. criteria that would be relevant to judging the legitimacy of secession - evidence of popular support for independence and whether federal institutions still allowed for adequate representativeness and participation. The moral arguments from consent and based on remediation of discrimination were given international legal consequences indirectly, without an explicit affirmation of their normative weight or an analysis of exactly how they can or should be translated into legal principle. Thus our first notion, the need for clarity concerning the moral arguments underpinning the claim for a right to external self-determination and the challenge of translating them into legal principle, was not well-reflected in the Badinter Commission's opinions.

The Commission was faced with the difficulty the guidelines posed with respect to the demand for territorial stability. Did recognition imply accepting whatever territory the independence movement controlled at the moment at which recognition was determined? Avoiding the implications of such a con-

41 Peter Radan, Post-Secession International Borders: A Critical Analysis of the Opinions of the Badinter Arbitration Commission, 24 (1) MelbourNe U. L. Rev. 50 (2000). 
secration of rapports de force, the Commission pulled out of a hat uti possedetis. ${ }^{42}$ In a novel doctrinal move (uti possedetis had only clearly been recognized as valid law with respect to former colonial boundaries in the context of decolonization ${ }^{43}$ ), the Commission stated that uti possedetis would apply in such a way that recognition would be based on each of the independence movements being entitled to the territory of the federal sub-unit in which that movement was based. ${ }^{44}$ No more, no less, regardless of any normative or practical considerations. The internal federal boundaries of Yugoslavia would be the boundaries of the newly recognized states. (Opinions 2 and 3) Serbs and Croats in Bosnia-Herzegovina (and Croats in Serbia) would be entitled to minority rights but nothing more. To legitimize the choice of uti possedetis here the Commission pointed not only to the need for territorial stability and the avoidance of violent struggle over borders, but in a subtle and almost under the surface way to the confederal (and ethno-nationalist) notion that Yugoslavia was composed by republican "entities"; a federal state is "made up of a number of separate entities." 45

The idea here is that the natural or original political community is an entity based upon a single people or an ethnic or national majority; the federation is a composite or derivative political community. Thus, it is no surprise that where these "entities" no longer wish to operate together a federal state, the federation would dissolve into separate states created out of these entities. But of course this is hardly the only theory of a federal polity. We point out only that an important judgment of normative political theory is embedded in what the Commission presents as a statement of obvious facts. ${ }^{46}$ If the republics were seen as mere administrative districts in an authoritarian state held together by a single political party and its various sociological emanations, then one would have to question the legitimacy of basing statehood on those boundaries; indeed, one might be inclined to the conclusion that the secessionist movements in the republics that were engineered by the various political elites were depriving the Yugoslav people of self-determination - the ability to decide together a post-communist - and perhaps even post-ethno-nationalist future. Thus, very

42 Opinion No 3 of the Arbitration Commission of the Peace Conference on Yugoslavia, Jan. 11, 1992, 31 ILM 1499 [hereinafter Opinion No 3].

43 See Case Concerning the Territorial Dispute [1994] ICJ Rep 6, 89 (Ajibola J.), cited in Radan, supra note 41, at n.60.

44 Opinion No. 3, supra note 42.

45 Opinion No. 8, July 1992 (Completing the process of the dissolution of the Socialist Federal Republic of Yugoslavia (SFRY)).

46 For a critique of the pact theory, see Robert Howse \& Karen Knop, Federalism, Secession, and the Limits of Ethnic Accommodation, 1 NEw EuR. L. Rev. 269 (1992-1993). 
indirectly the Commission acquiesced to elements of the ethno-nationalist moral argument for self-determination.

There were at least three respects in which the Badinter Opinions, and the Guidelines and Declaration they were interpreting, created perverse incentives, rewarding "ethnic cleansing." First of all, the requirement of uti possedetis having eliminated the possibility of adjusting borders to the ethno-national ideologies of the various political groups, the obvious alternative was to "adjust" the population within the borders of each of the entities to the demands of these ideologies.

Second, in requiring very extensive protection of minority rights, and respect for non-discrimination, the criteria applied by the Badinter Commision would make it difficult for the dominant political group within each entity to operate the state as an expression of ethno-nationalist ideology, as long as significant minority populations remained within their territory. This made it desirable for the ethno-nationalist majority to encourage those populations to leave and return to their own "homeland," so that the majority would have a freer hand to exercise collective power in the service of group identity.

Third, the Commission opined that the members of minority groups in the newly recognized states had a right to choose their "nationality." 47 The Commission drew out the implications of this only obscurely, one of them being that it might be possible for Bosnian Serbs to choose to be nationals of Serbia (assuming Serbia agreed). They had a national homeland in Serbia to which they could choose to belong. Why then should not the majority in Bosnia "encourage" them to make this choice?

Finally, in determining on the one hand that minorities within the territory of each of the former republics - the newly recognized states - would be entitled to a wide range of minority rights, and on the other hand that no changes in boundaries could be contemplated, the Badinter Commission was silent on the remedies available if the newly recognized states refused to respect the human and minority rights of the minorities: In that one case, would secession be still available as a remedy, or would the principle of inviolability of post-independence frontiers preclude even remedial secession? Again here we see a lack of clarity about the nature of the moral arguments and what is required to translate them into legal principle.

But these difficulties in the Badinter approach may have ultimately led in later phases of the Balkans conflict to a stronger reflection of some of the other central notions we believe are needed for a comprehensive approach to the international legal regulation of external self-determination. The establishment

47 Opinion 3, supra note 42. 
of an international criminal tribunal led to criminal responsibility for many acts of violence committed in the struggle for self-determination in the Balkans, responsibility applying to non-state as well as state actors and to internal as well as external aspects of the conflict. ${ }^{48}$ This is perhaps the strongest expression yet of the fourth notion, which is that all the actors, state and non-state should be international legally responsible for their conduct through the process of asserting the claim to external self-determination and responding to it. It is also a reflection of our second notion that the right to external self-determination must be defined in relation to other international legal norms and not trump them, and the third notion of a continuum of legal regulation-ethnic cleansing and related acts of persecution have be deployed as means in the struggle for external self-determination, and also in the exercise of it, once statehood has been achieved.

The prohibition on ethnic cleansing implies a hard limit on the ethnonationalist moral argument for external self-determination or at least a hard limit on its translation into international legal principle. Ultimately, the logic of that prohibition is that a group exercising external self-determination as the controlling majority within a state is considerably limited in the tools that it can use, consistent with international law, to assure that the demographics remain in its favor: i.e. that the group remains a numerical majority in the state and is thus able to ensure that its institutions and policies reflect and preserve the collective identity in question. In other words, that group cannot engage in coercive policies, at the very least actual forcible expulsion, to reduce the presence of members of other groups on the territory of the state in question. While the jurisprudence of the ICTY suggests that forcible expulsion or removal of a population group is criminally prohibited under international law, ${ }^{49}$ it is arguable that many actions that fall short of forcible removal, but which involve the intimidation of such groups or reducing their legal protections in such a way as to make it practically impossible for them to live as equal citizens in the state in question, would also amount to prohibited "ethnic cleansing." Thus under the statute of the International Criminal Court, whose provisions were deeply influenced by criminal justice in the Balkans, among the list of criminal offenses over which the Court has jurisdiction are "inhumane" acts including persecution, "the intentional and severe deprivation of fundamental rights contrary to international law or by reason of the identity of the group or collectivity. ${ }^{50}$

48 This is developed at length in Terrel, supra note 6, chs. 4 and 5.

49 See Prosecutor v. Krstić, Case No IT-98-33-T, Trial Chamber Judgment, Aug. 2, 2001.

50 Rome Statute of the International Criminal Court, art. 2 (g), July 17, 1998, 2187 U.N.T.S. 90. 
But the tension here may not only be with the ethno-nationalist moral argument. For the remedial argument as well assumes that a group needs to have its "own" state in order to counter adequately discrimination or persecution. If some other group becomes the governing majority, if only through demographic change, then the risks of discrimination or persecution in theory are revived; and yet, again, actively countering such a change may well run afoul of other international legal norms.

Finally, the Balkans conflict also saw an eventual expression of our related fifth notion that political and diplomatic institutions should not be allowed to foreclose or prejudge claims of persons and peoples who lack standing before those state-dominated institutions, leaving space for other fora to vindicate such international legal claims. This is most clearly illustrated in European Court of Human Rights case of Sedjić and Finci v. Bosnia and Herzogovina..$^{51}$ According to the Constitution of Bosnia (originating in the Dayton Accord), the applicants before the ECHR, who were of Roma and Jewish origin, were ineligible to stand for election to the House of Peoples of Bosnia (the second chamber of the State parliament) and to the Presidency (the collective Head of State). ${ }^{52}$ Eligibility for either office required affiliation with a "constituent people" of Bosnia (Serb, Croat or Muslim). ${ }^{53}$ Finding a violation of the equality provisions of the European Convention on Human Rights, the Court held:

Racial discrimination is a particularly egregious kind of discrimination and, in view of its perilous consequences, requires from the authorities special vigilance.... It is for this reason that the authorities must use all available means to combat racism, thereby reinforcing democracy's vision of a society in which diversity is not perceived as a threat but as a source of enrichment.

The Court found that the need for power-sharing as part of the political settlement in Bosnia was not "an objective and reasonable justification" for the discriminatory policy because power sharing could be achieved without the "total exclusion of representatives of the other communities." 54

One cannot underestimate the significance of the Court's decision here for the approach we advocate to the international legal regulation of external selfdetermination. The international community decided to deny to each of the main groups within Bosnia the right of external self-determination, a decision already

51 Sejdić and Finci v. Bosnia and Herzegovina: Applications nos. 27996/06 and 34836/06, Eur. Ct. H.R. (Dec. 22, 2009), Grand Chamber judgment.

52 Id. para. 9.

53 Id. at 3, para. 7.

$54 \mathrm{Id}$. paras. 43, 50, and 48. 
predetermined by the endorsement of $u$ ti possedetis by the Badinter Commission. Instead, each group was granted vested collective rights in the governance of the composite state of Bosnia-Herzegovina. The European Court of Human Rights rejected the notion of the arrangement as a final settlement of the claims in question, fully subjecting it to generally applicable human rights norms. In other words, any aspect of a political agreed solution with respect to the exercise of the right to self-determination is reviewable against such human rights norms ex post, at the behest of affected individuals or groups.

But the Sejdic and Finci case also has important implications for translation of the moral argument for self-determination on ethno-nationalist lines into international legal principle. The Court's understanding of democratic equality, i.e. of non-discrimination in political participation, essentially ruled out the possibility of reserving political offices to individuals identifying with particular ethno-national groups. Its approach thus raises the question of whether there is an intrinsic incompatibility between international human rights norms of a fundamental character and the idea that the exercise of collective power by representatives of a particular ethno-nationalist group is a legitimate aim of external self-determination.

\section{Quebec: The Supreme Court of Canada Opinion on Secession}

In a reference opinion, the Supreme Court of Canada considered whether, under the Canadian constitution and under international law, the province of Quebec had a right of unilateral secession from Canada. ${ }^{55}$ The Court's articulation of its understanding of democracy and peoplehood within a federal state encompassing different linguistic and ethnic groups is relevant to the meaning of external self-determination in international law, even though it occurs in the part of the ruling dealing with Canadian constitutional law.

The Court summarized its approach under the Constitution as follows:

The Court in this Reference is required to consider whether Quebec has a right to unilateral secession. Arguments in support of the existence of such a right were primarily based on the principle of democracy. Democracy, however, means more than simple majority rule. Constitutional jurisprudence shows that democracy exists in the larger context of other constitutional values. Since Confederation, the people of the provinces and territories have created close ties of interdependence (economic, social, political and cultural) based on

55 Reference re Secession of Quebec, [1998] 2 S.C.R. 217. 
shared values that include federalism, democracy, constitutionalism and the rule of law, and respect for minorities. A democratic decision of Quebecers in favor of secession would put those relationships at risk. The Constitution vouchsafes order and stability, and accordingly secession of a province "under the Constitution" could not be achieved unilaterally, that is, without principled negotiation with other participants in Confederation within the existing constitutional framework. ${ }^{56}$

The Court further opined:

Quebec could not, despite a clear referendum result, purport to invoke a right of selfdetermination to dictate the terms of a proposed secession to the other parties to the federation. The democratic vote, by however strong a majority, would have no legal effect on its own and could not push aside the principles of federalism and the rule of law, the rights of individuals and minorities, or the operation of democracy in the other provinces or in Canada as a whole. Democratic rights under the Constitution cannot be divorced from constitutional obligations. Nor, however, can the reverse proposition be accepted: the continued existence and operation of the Canadian constitutional order could not be indifferent to a clear expression of a clear majority of Quebecers that they no longer wish to remain in Canada. The other provinces and the federal government would have no basis to deny the right of the government of Quebec to pursue secession should a clear majority of the people of Quebec choose that goal, so long as in doing so, Quebec respects the rights of others. The negotiations that followed such a vote would address the potential act of secession as well as its possible terms should in fact secession proceed. There would be no conclusions predetermined by law on any issue. Negotiations would need to address the interests of the other provinces, the federal government and Quebec and indeed the rights of all Canadians both within and outside Quebec, and specifically the rights of minorities.

The negotiation process would require the reconciliation of various rights and obligations by negotiation between two legitimate majorities, namely, the majority of the population of Quebec, and that of Canada as a whole. A political majority at either level that does not act in accordance with the underlying constitutional principles puts at risk the legitimacy of its exercise of its rights, and the ultimate acceptance of the result by the international community. ${ }^{57}$

It will be noticed here that the Supreme Court of Canada gives some weight (as does the Badinter Commission albeit under the guise, as we argued, of making a purely factual determination) to the moral argument from consent. But the Court also has a clear sense of the difficulty with translating that moral argument into a legal entitlement to external self-determination: the need to respect the rights of others, with whom the group in question has shared a political and legal community on the territory in question.

56 Id.

57 Id. (2) Question 1. 
Second, contrary to the Badinter Commission, the Canadian Court chooses to view the expression of popular will in favor of independence not as a stage in the dissolution of the federal state but rather as triggering a negotiation with the people of the country as a whole as represented by the federal level of government. The Court does not view Canada as a union of peoples or provincial "entities": thus it speaks of a Canadian as well as a Quebec "political majority." One can of course explain the differences in terms of the different factual circumstances. Given that the Yugoslav federal state was controlled by an authoritarian one-party government, could one speak of a political majority of the Yugoslav people as a whole, other than in connection with the hope of a democratic post-Communist transition for Yugoslavia as a whole? Further, in its constitutional analysis, the Canadian Supreme Court did not exclude "boundary issues" from the many and complex questions that would need to be resolved by negotiations within the framework of the rule of law. Thus, it by no means endorsed the validity of the existing provincial boundaries as a basis for secession or dismemberment of the country in accordance with the principles of democracy, constitutionalism and the rule of law, federalism and protection of minorities. Finally, the Court viewed the conformity of the negotiations over secession with the constitutional principles as non-justiciable; here one needed to rely on the political actors to protect constitutional values. But the Court observed, "the legality of the acts of the parties to the negotiation process under Canadian law, and the perceived legitimacy of such action, would be important considerations in the recognition process. $" 58$

The court thus assumed that, at the international level, recognition could depend on the legitimacy of the process of secession; that this legitimacy would in part be evaluated as against the standards of the Canadian constitutional order itself. By contrast the Badinter Commission's conception of recognition as flowing from "dissolution" of a federal state suggests that secessionist movements have every incentive to break down the rule the law, using methods that render the institutions of the federation and indeed the federal level of governance itself as non-functional, so as to be able to provoke a verdict of "dissolution" that allows recognition of the seceding state within the boundaries established by the constitution of the federal union.

This brings us to the international legal analysis proper of the Canadian Supreme Court. The Court opined:

International law contains neither a right of unilateral secession nor the explicit denial of such a right, although such a denial is, to some extent, implicit in the exceptional

58 Id. para. 103. 
circumstances required for secession to be permitted under the right of a people to selfdetermination, e.g., the right of secession that arises in the exceptional situation of an oppressed or colonial people, discussed below. ${ }^{59}$

Despite the Court's remarks about the implications of legality and legitimacy for recognition at the end of its discussion of the Canadian constitution, when discussing international law the Court contemplates the possibility that a valid act of recognition under international law need not be based on the legality and legitimacy of external self-determination: international law permits the recognition of statehood even where external self-determination is not legal under international law. The Court notes a trend towards linking recognition to legitimacy, invoking to the EU Guidelines, and refers back to its earlier remarks, but in the last analysis, its view of the law is that there is no requirement to deny recognition to a state that is the product of an illegal secession process. ${ }^{60}$ But the corollary of this - which the Court was equally if not more concerned with is that the fact of recognition by any given state or group of states cannot be used to establish a right to statehood in international law. We would draw a further consequence, based on our fourth notion, concerning continuous and generalized international responsibility, recognition should not mean (as was often at least implied or assumed traditionally) endorsement of the struggle for external self-determination or operate as a justification or excuse for otherwise internationally wrongful acts committed in that struggle.

One of the most interesting elements in the Canadian Court's opinion on international law is its discussion of peoplehood. The Court, ostensibly from judicial economy, refuses to decide whether the Francophone majority of Quebec constitutes a "people"; this is because, as is discussed presently, the Court finds that even if it were a "people," it would not have a right to secession since the only such right, other than in the case of decolonization, is a remedial right in the case of oppression.

The Court remarked: "much of the Quebec population certainly shares many of the characteristics (such as a common language and culture) that would be considered in determining whether a specific group is a 'people,' as do other groups within Quebec and/or Canada,..." ${ }^{61}$ This statement must be understood together with the Court's failure to exclude "border issues" from the matters that would need to be negotiated as part of a lawful secession under the Canadian constitution. The claim of the francophone majority or its political representatives to secession based on the existing boundaries of the

59 Id. para. 112.

$60 \mathrm{Id}$. para. 143.

$61 \mathrm{Id}$. para. 125 (emphasis added). 
province of Quebec would have to be weighed against the claims of other groups within Quebec who also, and equally, qualify as "peoples" for purposes of self-determination.

The Court's choice not to decide the legal meaning of "people" for purposes of the right to self-determination in international law is significant. It was implicitly rejecting a meaning to the right to self-determination that would give the majority "group" on the territory of a federal sub-unit some kind of privileged claim to realize independence within those boundaries, while relegating other groups to a lesser status, for example, that of an "ethnic group" in the Kymlicka typology. A right to external self-determination exists according to the Canadian Court either in circumstances of colonialism or foreign occupation or "where a definable group is denied meaningful access to government to pursue their political, economic, social and cultural development." ${ }^{\prime 2}$ Thus, all but explicitly, the Canadian Court rejects the ethno-nationalist moral argument for a right to external self-determination: any definable group could be a "people" if its members are denied "meaningful access to government to pursue their political, economic, social and cultural development" on account of group membership. This justifies the jurisprudential choice of the Canadian Court to begin by asking whether there was such a denial rather than whether the francophone majority in Quebec as represented by the Quebec government was a "people."

The Canadian Court interpreted the meaning of "access to government to pursue ... political, economic, social and cultural development" not in terms of the adequacy of the political arrangements to the survival or flourishing of the defined group as a collectivity, but rather the openness without discrimination of the federal polity's political, economic, and social institutions to individual members of the defined group. The Canadian court rejected the argument of the Quebec independence movement that the failure of constitutional amendments enhancing the competences or autonomy of the Quebec government to represent the collective interests of the Francophone majority in "their political, economic, social and culture development" as a "group."63 All of the considerations alluded to by the Court go to the extent to which participation in the life of the country of Canada as a whole, including its political life, is afforded under the existing arrangements, and none concerned the adequacy of the federal arrangements, above all the competences

62 Id. para. 138.

63 Id. para. 121, citing Final Act of the Conference on Security and Co-operation in Europe, 14 I.L. M. 1292 (1975) (Helsinki Final Act). 
of the Quebec government, to allow for the use of collective power to express the Francophone Quebecois identity.

The Court opined (quoting extensively from an Amicus brief):

The population of Quebec cannot plausibly be said to be denied access to government. Quebecers occupy prominent positions within the government of Canada. Residents of the province freely make political choices and pursue economic, social and cultural development within Quebec, across Canada, and throughout the world. The population of Quebec is equitably represented in legislative, executive and judicial institutions. In short, to reflect the phraseology of the international documents that address the right to selfdetermination of peoples, Canada is a "sovereign and independent state conducting itself in compliance with the principle of equal rights and self-determination of peoples and thus possessed of a government representing the whole people belonging to the territory without distinction." 64

As can be seen, there is no discussion at all of the extent to which the existence of a democratic government within a territorial sub-unit of Canada where the majority is francophone contributes to the realization of the right to self-determination. The Court here seems to have grasped some of the difficulties of translating the ethno-nationalist moral argument into a workable, coherent international legal principle. Here we should note the Court's dicta that other groups within Quebec might equally be "peoples" with a right to self-determination. A Quebec government that privileged the collectivity represented by Francophone Quebeckers, even if a numerical majority, at the expense of other groups within the province, might itself engage state responsibility for a violation of the right to self-determination of those other peoples within the territory of Quebec, understood in terms of democratic equality.

Some years earlier the Canadian Court had held unconstitutional the exercise of competences of the Quebec government to limit the use of English in public signs in the province, in order to create a "visage linguistique" that expressed the collective identity of the Francophone majority, finding that such a policy was a violation of freedom of expression, and not justified as a limit on rights compatible with a "free and democratic society." 65 The Quebec government invoked the override or not-withstanding clause in the Canadian Charter of Rights and Freedoms to maintain the sign law in place. But then a complaint was brought before the United Nations Committee on Civil and Political Rights, which found that the Quebec law was in violation of

64 Id. para. 136.

65 Ford v. Quebec (Attorney General), [1988] 2 S.C.R. 712 (striking down part of the Charter of the French Language). 
international human rights norms. ${ }^{66}$ As with Sedjic and Finci v. Bosnia and Herzegovina, the UN Committee opinion in the sign law case illustrates the limits that international law places on the ability to exercise self-determination in a manner that advances an ethno-nationalist project by using collective power to protect a collective identity in ways that affect the rights of others.

The Canadian Court's approach to the legal regulation of external selfdetermination, in addition to displaying clarity about the nature and limits of the moral arguments underpinning the claim to external self-determination as a legal entitlement, also is consistent with two of the other notions that we believe are central to a "comprehensive answer": the notion that any right to external self-determination needs to be defined in relation to other legal norms and does not have the character of a "trump" over those norms, as well as the notion of a continuum of regulation that applies to acts long preceding the recognition of statehood, as well as responsibility under law after statehood is recognized.

With respect to this last notion, the Canadian court recognized that translating the moral argument from consent into a legal principle required the application of relevant legal norms to the process by which the will of the group in question to external self-determination is ascertained in the first place. But the Canadian court also suggests that there is an important issue about the democratic character of any such expression by plebiscite or referendum: thus it requires "a clear majority" and a "clear question." Also, as the Canadian court indicates, democracy is much more than a mere crude expression of popular will. The conditions under which any such expression of will takes place would be a significant element in the regulation of the exercise of external self-determination and would entail the application of international legal norms concerning freedom of expression and association, political pluralism, and the meaningful participation of minorities in the voting process. The Badinter Commission merely assumed that the various plebiscites and resolutions in the Yugoslav republics were valid democratic acts; Radan makes a powerful argument as to why that was not often the case. ${ }^{67}$

With respect to our fifth notion, that decisions in political and diplomatic bodies concerning claims of external self-determination do not foreclose the possibility of the claims of affected persons or groups with no standing before such bodies, the approach of the Canadian court to justiciability represents something of a setback. It is understandable that the Court would not want to micromanage the process by which the political actors negotiated secession or to have to make an overall judgment about the consistency of the result with the

66 Alan Singer v. Canada, Communication No. 455/1991.

67 Peter Radan, The Break Up of Yugoslavia and International Law ch. 7 (2002). 
constitutional and international law principles it enunciated. However, the Court left the impression that, if the rights of some individual or group were violated through the failure to respect those principles, no judicial remedy would be available once the matter was in the hands of the political actors. At the same time, it is true that a wide variety of individuals and groups whose rights would arguably be affected by the exercise of external self-determination by the Francophone majority in Quebec were able to appear before the Supreme Court as interveners. Also the Court emphasized that whatever might result from the interplay of the political actors in Canada would be subject to scrutiny at the international level.

\section{Conclusions}

As we noted at the beginning of this article, in the Kosovo Advisory Opinion, the International Court of Justice avoiding completely deciding the question of whether there is a right to external self-determination in international law and its limits and conditions. At the same time the Court noted in dicta: "Whether, outside the context of non-self-governing territories and peoples subject to alien subjugation, domination and exploitation, the international law of self-determination confers upon part of the population of an existing State a right to separate from that State, is ... a subject on which radically different views were expressed by those taking part in the proceedings and expressing a position on the question." 68

Similar differences existed regarding whether international law provides for a right of "remedial secession" and, if so, in what circumstances. 69

These disagreements reflect not only strongly held divergent views about the question of Kosovo independence but also the serious difficulties entailed in translating the common moral arguments for a right to external self-determination into workable legal principle of consistent application, and consistent with other, fundamental norms of international law. At the same time, the international legal regulation of external self-determination has become increasingly pervasive and comprehensive, even in the absence of clarity about the existence and extent of a right to external self-determination in international law, whether through human rights, the application of the law of war to conflicts concerning self-determination, or international criminal responsibility for actions in

68 Kosovo Advisory Opinion, supra note 1, para. 82.

$69 \mathrm{Id}$. 
struggles concerning self-determination such as ethnic cleansing or "persecution." A comprehensive theory of external self-determination in international law would need to take into account all of these evolving elements: the five interlocking notions we propose in this article, and which we explore in relation to recent developments in the law, are intended as a possible beginning point for the much more challenging task of developing such a theory. 